\title{
Biological Reduction of Hydrogel-Encapsulated Fe(III) by Shewanella oneidensis MR-1: Incubation Experiment and Kinetic Modeling
}

\author{
Youchi Zhang*, Huidan Li \\ Institute of Urban Environment, Chinese Academy of Sciences, \\ Jimei Road 1799, Xiamen, 361021, China
}

Received: 11 August 2015

Accepted: 9 December 2015

\begin{abstract}
Dissimilatory Fe(III) reduction has a profound influence on the global cycling of elements and the decontamination of pollutants, depending on the interaction of various environmental conditions. Hydrogelencapsulated goethite/soil was prepared in this study, and anaerobic incubation was conducted to investigate the biological Fe reduction of different encapsulated aggregates by Shewanella oneidensis MR-1. Results indicated that the release of $\mathrm{Fe}$ (II) ion was significant and insignificant in R-soil treatments with and without anthraquinone-2,6-disulfonate (AQDS), respectively. The increase in the cross-linker ratio in the hydrogel decreased iron reduction. The Fe(II) concentration followed the order of unencapsulated treatment $<0.3 \%$ encapsulated hydrogel treatment $<2 \%$ encapsulated hydrogel treatment with AQDS addition. The results of the goethite experiment suggested that the goethite level and the addition of AQDS changed the effect of mineral structure property on iron reduction. This result was consistent with the simulation of a reductive dissolution kinetic model, in which the initial iron reduction rate $k$ and long-term $\mathrm{Fe}$ (II) ion release extent parameter $\log \gamma$ were controlled by the interaction of the mineral structure property, iron mineral content, and electron shuttle compound distribution. Thus, site-specific environmental conditions should be fully considered in monitoring the performance and environmental effects of biological iron reduction.
\end{abstract}

Keywords: iron bioreduction, hydrogel encapsulation, electron shuttle mechanism, Shewanella oneidensis MR-1

\section{Introduction}

Dissimilatory $\mathrm{Fe}(\mathrm{III})$ reduction under anaerobic geochemical conditions is mediated by metal-reducing bacteria, which is an important biogeochemical process in soil, sediments, and subsurface environments $[1,2]$.

*e-mail: yczhang@iue.ac.cn

Bioreduction significantly affects the environmental redox state and buffering capacity [3, 4], which leads to changes in iron mineral structure properties and their geochemical reactivity $[5,6]$. Furthermore, coupled with the reduction of $\mathrm{Fe}(\mathrm{III})$ minerals, heavy metals, including copper and zinc, are redistributed within the soil environments [7, 8], whereas several organic pollutants such as aromatic hydrocarbons are degraded [9]. 
The growth and activity of metal-reducing microorganisms are affected by the interaction of environmental factors, including iron mineral type and content, $\mathrm{pH}$, and carbon substrate concentration - factors that cause variations in the performance of biological iron reduction $[10,11]$. Previous research found that the extent of the reductive dissolution of highly crystalline iron minerals is lower than the reduction of amorphous and poorly crystalline iron oxyhydroxides [10]. Bose et al. (2009) [12] reported that the reductive dissolution rate of hematite nanoparticles are not always positively correlated with particle size, whereas Yan et al. (2008) [13] suggested that the bacteria-hematite contact surface area may be the dominant factor affecting iron reduction instead of the total hematite surface area. Iron minerals are usually present within soil aggregates, which might suppress the contact and reduction of metal-reducing microorganisms (e.g., Shewanella oneidensis). Thus, the performance of iron reduction is influenced by different aggregate structure properties of soils. Electron shuttle compounds (i.e., anthraquinone-2,6-disulfonate (AQDS), humic acid, and flavin) have been reported to assist metal-reducing microorganisms in the bioreduction of iron minerals far from the bacteria or within small pore structures that inhibit the entrances of bacteria [14]. Low levels of humic acid as an electron shuttle compound limit or inhibit ferrihydrite bioreduction, whereas the decrease in ferrihydrite concentration or the increase in humic acid levels increases Fe(II) ion concentrations [15]. Different types of soil present unique aggregate structures in nature and may affect biological iron reduction even with the electron shuttle mechanism.

This study aimed to improve the understanding of iron reduction in soils/sediments with different structural properties and environmental conditions. The hydrogel encapsulation technique was used to prepare hydrogelencapsulated iron oxyhydroxides and soil to simulate soil aggregates with different structural properties. Anaerobic batch experiments were conducted to investigate the kinetics of iron reduction in aggregates using the typical iron reducer $S$. oneidensis MR-1 and electron shuttle AQDS. A reductive dissolution kinetic model was also used to characterize the experimental data and provide further information on the iron reduction of different aggregates.

\section{Materials and Methods}

\section{Materials}

\section{S. Oneidensis MR-1 Preparation}

S. oneidensis MR-1 cells were cultured at $25^{\circ} \mathrm{C}$ in Luria-Bertani medium, which contained $10 \mathrm{~g} \mathrm{~L}^{-1}$ tryptone, $5 \mathrm{~g} \mathrm{~L}^{-1}$ yeast extract, and $5 \mathrm{~g} \mathrm{~L}^{-1} \mathrm{NaCl}$ with $\mathrm{pH}$ 7.0. After centrifuging at 7,000 rpm for $15 \mathrm{~min}$ at $4^{\circ} \mathrm{C}$, the harvested cells were washed three times with $12 \mathrm{mmol} \mathrm{L}^{-1}$ HEPES (N-2-hydroxyethylpiperazine-N)-2-ethanesulphonic
acid)-pH buffer solution [16]. The suspensions of S.oneidensis MR-1 cells were collected and used for iron reduction experiments.

\section{Synthetic Goethite Preparation}

Synthetic goethite $(\alpha-\mathrm{FeOOH})$ was prepared following the procedure of Lovley and Phillips (1986) [17]. In brief, the $\mathrm{pH}$ of a $0.4 \mathrm{~mol} \mathrm{~L}^{-1} \mathrm{FeCl}_{3}$ solution was adjusted to 12.0 with $\mathrm{NaOH}$ solution. After one week at room temperature, the solution was incubated at $90^{\circ} \mathrm{C}$ for $16 \mathrm{~h}$ and then freeze-dried. According to X-ray diffraction analysis, the synthetic iron oxide was confirmed to be goethite.

\section{Experimental Soil}

R-soil samples were collected from Fujian Province in southern China. According to the Chinese soil classification, the R-soil sample was Ferrisol, which was classified as a typical kandiudult according to the United States Department of Agriculture (USDA) and as ferric acrisols according to the FAO/UNESCO soil classification system. The physicochemical characteristics of the experimental soils are presented in Table 1.

\section{Preparation of Hydrogel-Encapsulated Aggregates}

Hydrogel-encapsulated aggregates were prepared according to a modified Spalding's procedure [18]. A total of $0.4 \mathrm{~g}$ of synthetic goethite (or $1 \mathrm{~g}$ of soil) was mixed and stirred with $2 \mathrm{~mL}$ of hydrogel-forming solution in a $2.5 \mathrm{~mL}$ syringe that contains $14 \%$ monomer

Table 1. The physico-chemical characteristics of R-soils.

\begin{tabular}{|c|c|c|}
\hline Item & Unit & Value \\
\hline $\mathrm{pH}$ & & $4.6 \pm 0.1$ \\
\hline Total organic carbon & $\mathrm{g} \mathrm{kg}^{-1}$ & $1.52 \pm 0.13$ \\
\hline Cation exchange capacity & $\mathrm{cmol} \mathrm{kg}^{-1}$ & $3.08 \pm 0.05$ \\
\hline \multicolumn{3}{|c|}{ Particle distribution } \\
\hline Sand $(0.02-2 \mathrm{~mm})$ & \multirow{3}{*}{$\%$} & $42.9 \pm 1.3$ \\
\hline Silt $(0.002-0.02 \mathrm{~mm})$ & & $43.8 \pm 0.8$ \\
\hline Clay $(<0.002 \mathrm{~mm})$ & & $13.3 \pm 0.7$ \\
\hline \multicolumn{3}{|c|}{ Element composition } \\
\hline $\mathrm{Si}$ & \multirow{8}{*}{$\mathrm{g} \mathrm{kg}^{-1}$} & $380 \pm 21$ \\
\hline $\mathrm{Al}$ & & $190 \pm 17$ \\
\hline $\mathrm{Fe}$ & & $40.0 \pm 0.3$ \\
\hline K & & $1.97 \pm 0.16$ \\
\hline $\mathrm{Ca}$ & & $0.52 \pm 0.20$ \\
\hline $\mathrm{Na}$ & & $2.60 \pm 0.33$ \\
\hline $\mathrm{Mg}$ & & $0.60 \pm 0.04$ \\
\hline $\mathrm{Mn}$ & & $0.29 \pm 0.02$ \\
\hline
\end{tabular}


Table 2. The structural properties of different hydrogelencapsulated aggregates.

\begin{tabular}{|c|c|c|}
\hline R-soil & $\begin{array}{c}\text { Surface area } \\
\left(\mathrm{m}^{2} \mathrm{~g}^{-1}\right)\end{array}$ & $\begin{array}{c}\text { Average pore } \\
\text { volume }\left(\mathrm{cm}^{3} \mathrm{~g}^{-1}\right)\end{array}$ \\
\hline $\begin{array}{c}0.3 \% \text { hydrogel } \\
\text { encapsulated R-soil }\end{array}$ & 10.14 & 0.17 \\
\hline $\begin{array}{c}2 \% \text { hydrogel } \\
\text { encapsulated R-soil }\end{array}$ & 1.39 & 0.065 \\
\hline $\begin{array}{c}\text { Goethite } \\
\text { 0.3\% hydrogel } \\
\text { encapsulated goethite }\end{array}$ & 26.1 & 0.25 \\
\hline $\begin{array}{c}2 \% \text { hydrogel } \\
\text { encapsulated goethite }\end{array}$ & 1.00 & 0.17 \\
\hline
\end{tabular}

acrylamide, $\quad 0.1 \%$ ammonium persulfate, $0.06 \%$ tetramethylethylenediamine, and $0.3 \%$ or $2 \%$ cross-linker $\mathrm{N}, \mathrm{N}^{\prime}$-methylene-bis-acrylamide (all at weight/volume). After initial polymerization, the syringes were stored at $4^{\circ} \mathrm{C}$ overnight to complete the polymerization process. The hydrogel-encapsulated aggregates were then removed from the syringes. The aggregates were rinsed three times with deionized water, cut into small pieces with $0.5 \mathrm{~cm}$ depth, and stored under water-saturated conditions. The structural properties of the aggregates are listed in Table 2.

\section{Biological Iron Reduction Experiments}

Iron reduction experiments were conducted in LML medium containing $10 \mathrm{mmol} \mathrm{L}^{-1}$ lactate as electron donor and $12 \mathrm{mmol} \mathrm{L}^{-1}$ HEPES as $\mathrm{pH}$ buffer [16]. A total of $29 \mathrm{~mL}$ of LML medium and certain grams of hydrogelencapsulated goethite/soils were placed in $60 \mathrm{~mL}$ serum bottles, the headspaces of which were replaced with pure $\mathrm{N}_{2}$ gas. The serum bottles were covered with butyl rubber stoppers and aluminum caps. About $1 \mathrm{~mL}$ of $S$. oneidensis MR-1 suspension was added into the bottle using a sterile syringe through the butyl rubber stopper. The mixture yielded a final concentration of $\sim 2 \times 10^{5}$ cells $\mathrm{mL}^{-1}$, and the media were incubated at $25^{\circ} \mathrm{C}$ in the dark. The sterilized samples were also subjected to treatment, with three replicates prepared for each treatment. The three-structure property treatments for either synthetic goethite or soil were as follows: a) hydrogel encapsulation at $0.3 \%$ cross-linker density, b) hydrogel encapsulation at $2 \%$ cross-linker density, and c) without hydrogel encapsulation. Concentrations of 3.3 and $6.6 \mathrm{~g} \mathrm{~L}^{-1}$ were used in the goethite experiment. In the soil experiment, $10 \mathrm{~g} \mathrm{~L}^{-1}$ soil was added to either aggregate. Traditional electron shuttle compound AQDS was also added into the LML medium in some experiments.

\section{Sampling and Analysis}

During the iron reduction experiments, $0.5 \mathrm{~mL}$ of suspension was sampled from the serum bottle using a sterilized syringe at intervals. The suspension was centrifuged at 10,000 rpm for $2 \mathrm{~min}$. The concentration of $\mathrm{Fe}(\mathrm{II})$ ion in the supernatant was measured by phenanthroline spectrophotometry [11].

\section{Kinetic Modeling}

The kinetic reductive dissolution of goethite was interpreted by a standard generalized rate law $[19,20]$ :

$$
\frac{J_{t}}{m_{0}}=k\left(\frac{m_{t}}{m_{0}}\right)^{\gamma}
$$

...where $J_{t}$ is the rate of reductive dissolution at time $t$, $m_{0}$ is the initial mass of iron, $m / m_{0}$ is the non-reductive dissolved iron fraction, $k$ is the initial rate constant, and $\gamma$ is a controlling parameter of the long-term release extent of $\mathrm{Fe}(\mathrm{II})$ ion.

As previously found by Davranche et al. (2013) [21], the reductive dissolution data of iron can be well fitted in OriginPro 8.0 (OriginLab corportation, USA) by the integrated form of Eq. (2):

$$
\frac{m_{t}}{m_{0}}=[1-k \cdot(1-\gamma) \cdot t]^{\frac{1}{1-\gamma}}
$$

\section{Results}

\section{Iron Reduction of Soil Aggregates with S. oneidensis MR-1}

Fig. 1 shows that Fe(II) ion release was lower than $0.5 \mathrm{mg} \mathrm{L}^{-1}$ for R-soil in the treatments without AQDS during incubation with $S$. oneidensis MR-1. By contrast, the addition of $100 \mu \mathrm{mol} \mathrm{L}^{-1}$ AQDS significantly increased the $\mathrm{Fe}(\mathrm{II})$ concentrations. The $\mathrm{Fe}(\mathrm{II})$ ion concentrations at the 10th day of unencapsulated R-soil treatment were $2.61 \pm 0.01$ and $0.08 \pm 0.03 \mathrm{mg} \mathrm{L}^{-1}$ with and without AQDS, respectively. In addition, the release of $\mathrm{Fe}(\mathrm{II})$ ions from unencapsulated R-soil was the highest among the three treatments with AQDS addition. The $\mathrm{Fe}(\mathrm{II})$ ion concentration in R-soil treatment after 42 days of incubation was $14.00 \pm 0.98 \mathrm{mg} \mathrm{L}^{-1}$, which was higher than the $\mathrm{Fe}(\mathrm{II})$ ion concentration in $0.3 \%$ hydrogel treatment $\left(6.92 \pm 1.23 \mathrm{mg} \mathrm{L}^{-1}\right)$ or in $2 \%$ hydrogel treatment $\left(3.74 \pm 2.12 \mathrm{mg} \mathrm{L}^{-1}\right)$. Thus, the structural property played an important role during the release of $\mathrm{Fe}(\mathrm{II})$ ion through biological iron reduction.

\section{Iron Reduction of Goethite Aggregates with S. oneidensis MR-1}

To understand the effects of structural property and AQDS addition on iron reduction, further experiments were conducted using goethite, which is one of the major bioavailable iron minerals in red earth soil. Fig. 2a shows 
that the $\mathrm{Fe}(\mathrm{III})$ ion concentrations in $3.3 \mathrm{~g} \mathrm{~L}^{-1}$ goethite treatments without AQDS were consistently less than $0.6 \mathrm{mg} \mathrm{L}^{-1}$ during incubation. The $\mathrm{Fe}$ (II) ion concentrations in the treatments with $100 \mu \mathrm{mol} / \mathrm{L}$ AQDS gradually increased during incubation with $S$. oneidensis MR-1. The $\mathrm{Fe}(\mathrm{II})$ ion concentration at day 10 was higher than $1 \mathrm{mg}$ $\mathrm{L}^{-1}$ in either treatment with AQDS, and the peak Fe(II) concentration for goethite without hydrogel encapsulation was found on day 20 (i.e., $2.59 \pm 0.41 \mathrm{mg} \mathrm{L}^{-1}$ ). The concentrations were reduced to $2.29 \pm 0.86 \mathrm{mg} \mathrm{L}^{-1}$ on day 28. By contrast, the $\mathrm{Fe}(\mathrm{II})$ concentrations in treatments with $0.3 \%$ and $2 \%$ hydrogel encapsulation were $1.38 \pm 0.10$ $\left(10^{\text {th }}\right.$ day) and $1.09 \pm 0.05 \mathrm{mg} \mathrm{L}^{-1}\left(14^{\text {th }} \mathrm{day}\right)$, respectively. The Fe(II) concentrations at the end of incubation still followed the order of goethite treatment $>0.3 \%$ hydrogel treatment $>2 \%$ hydrogel treatment.

Meanwhile, the $\mathrm{Fe}(\mathrm{II})$ ion concentration in treatments with high goethite contents $\left(6.6 \mathrm{~g} \mathrm{~L}^{-1}\right)$ rapidly increased (Fig. 2b). The concentration peaked at $5.22 \pm 0.90 \mathrm{mg} \mathrm{L}^{-1}$ on day 13. However, the $\mathrm{Fe}$ (II) concentration remained less than $0.7 \mathrm{mg} \mathrm{L}^{-1}$ during incubation in treatments with either $0.3 \%$ or $2 \%$ hydrogel encapsulation. The $\mathrm{Fe}(\mathrm{II})$ ion concentration significantly increased with the addition of $100 \mu \mathrm{mol} \mathrm{L}{ }^{-1}$ AQDS, whereas the Fe(II) ion concentrations in treatments with either $0.3 \%$ or $2 \%$ hydrogel encapsulation were significantly higher than those of treatments without hydrogel encapsulation. The peak of $\mathrm{Fe}$ (II) concentration was lower than $11 \mathrm{mg} \mathrm{L}^{-1}$ in the treatment with unencapsulated goethite, whereas the peaks of $\mathrm{Fe}(\mathrm{II})$ concentration in treatments with either $0.3 \%$ or $2 \%$ hydrogel encapsulation were $15.40 \pm 1.92$ and

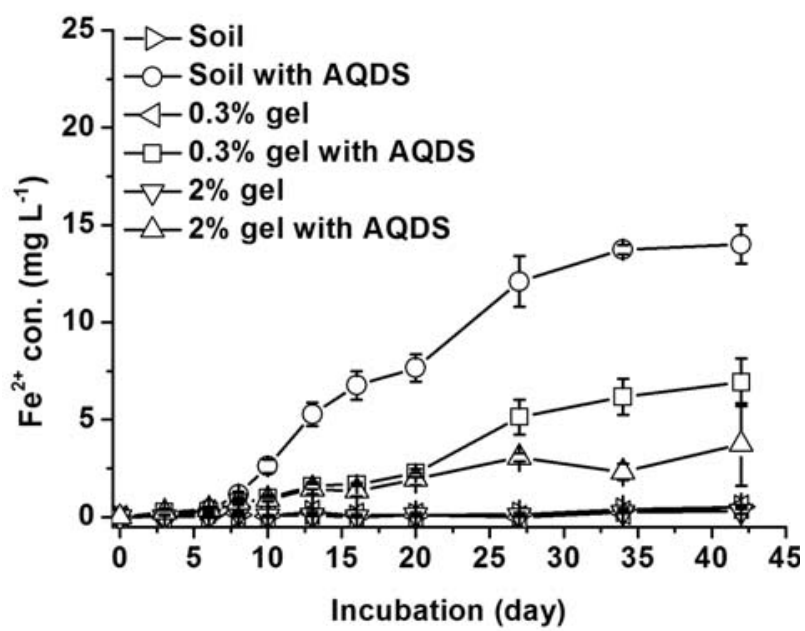

Fig. 1. Dynamics of $\mathrm{Fe}(\mathrm{II})$ ion concentrations during biological reductive dissolution of hydrogel-encapsulated R-soil. Six treatments were prepared, namely soil (right triangle), soil with AQDS addition (circle), $0.3 \%$ hydrogel-encapsulated soil (left triangle), $0.3 \%$ hydrogel-encapsulated soil with AQDS addition (square), $2 \%$ hydrogel-encapsulated soil (down triangle), and 2\% hydrogel-encapsulated soil with AQDS addition (up triangle). The soil content was $10 \mathrm{~g} \mathrm{~L}^{-1}$, whereas the addition of AQDS in some treatments was $100 \mu \mathrm{mol} \mathrm{L}{ }^{-1}$.
$15.53 \pm 0.29 \mathrm{mg} \mathrm{L}^{-1}$, respectively. The $\mathrm{Fe}(\mathrm{II})$ ion concentration after incubation followed the sequence: goethite treatment $\left(7.61 \pm 3.96 \mathrm{mg} \mathrm{L}^{-1}\right)<0.3 \%$ hydrogel treatment $\left(10.19 \pm 1.53 \mathrm{mg} \mathrm{L} \mathrm{L}^{-1}\right)<2 \%$ hydrogel treatment $\left(13.30 \pm 1.14 \mathrm{mg} \mathrm{L} \mathrm{L}^{-1}\right)$. However, with higher amounts of AQDS (150 or $300 \mu \mathrm{mol} \mathrm{L} \mathrm{L}^{-1}$ AQDS), the $\mathrm{Fe}(\mathrm{II})$ ion concentrations in unencapsulated goethite treatments were higher than those in treatments with $2 \%$ hydrogel encapsulation (Fig. 3). The Fe(II) ion concentration in unencapsulated goethite treatment with $300 \mu \mathrm{mol} \mathrm{L}{ }^{-1}$ AQDS quickly increased to over 47 $\mathrm{mg} \mathrm{L}^{-1}$ on day 6 , whereas the $\mathrm{Fe}(\mathrm{II})$ concentration in $2 \%$ hydrogel encapsulation treatment increased to only $40.35 \pm 5.96 \mathrm{mg} \mathrm{L}^{-1}$ after day 23 of incubation.

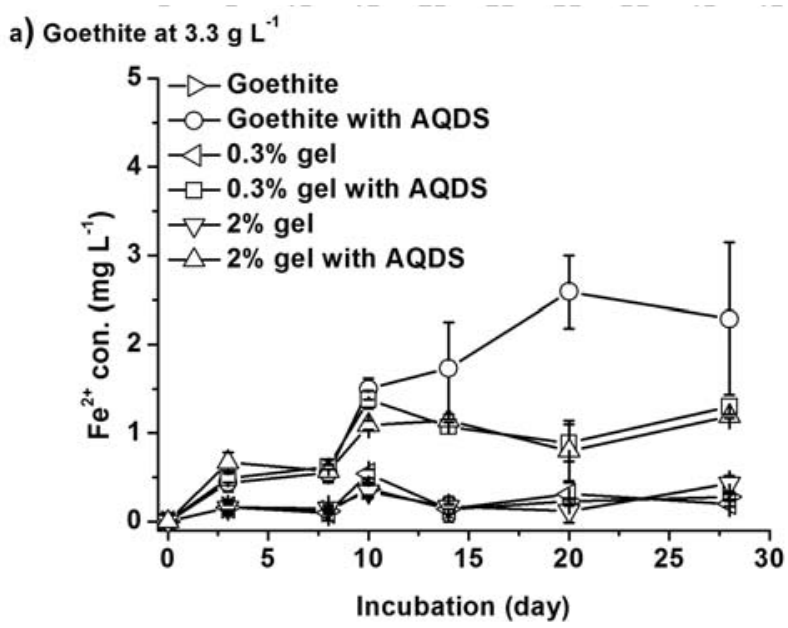

b) Goethite at $6.6 \mathrm{~g} \mathrm{~L}^{-1}$

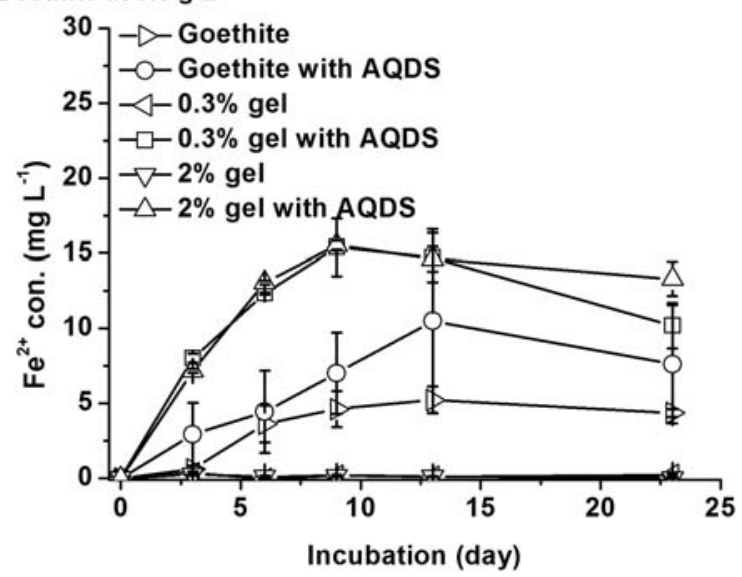

Fig. 2. Dynamics of Fe(II) ion concentrations during biological iron reduction with goethite aggregates. Six treatments were prepared, namely goethite (right triangle), goethite with AQDS addition (circle), $0.3 \%$ hydrogel-encapsulated soil (left triangle), $0.3 \%$ hydrogel-encapsulated soil with AQDS addition (square), $2 \%$ hydrogel-encapsulated soil (down triangle), and 2\% hydrogel-encapsulated soil with AQDS addition (up triangle). Two different kinds of goethite contents were prepared, namely 3.3 and $6.6 \mathrm{~g} \mathrm{~L}^{-1}$. The concentration of AQDS in some treatments was $100 \mu \mathrm{mol} \mathrm{L}^{-1}$. 
a) without $A Q D S$

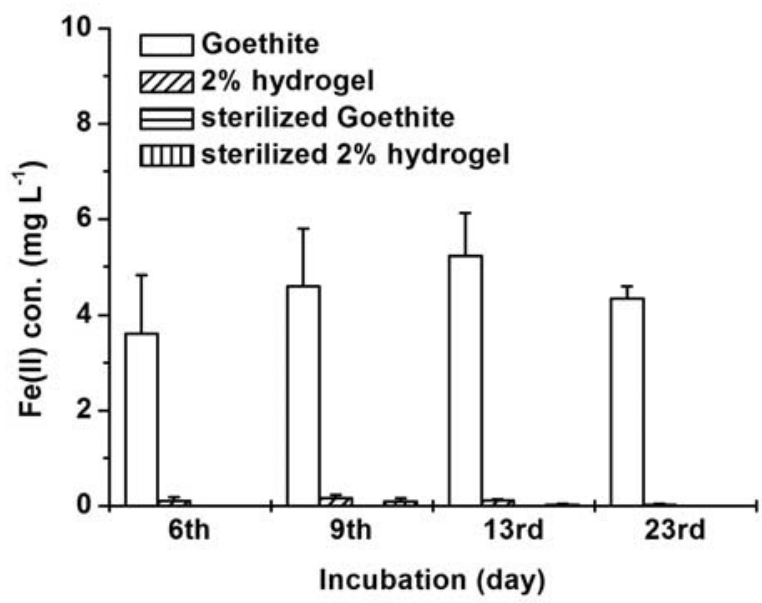

b) with $100 \mu \mathrm{mol} \mathrm{L}^{-1}$ AQDS

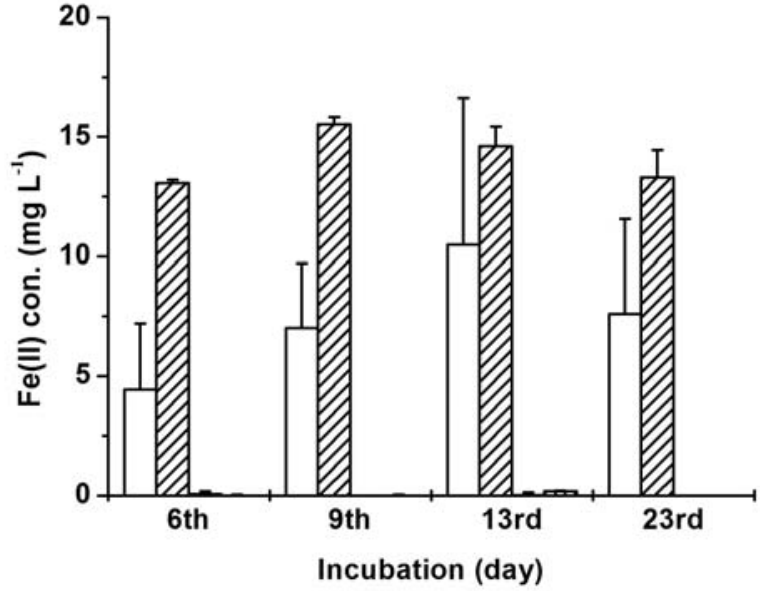

c) with $150 \mu \mathrm{mol} \mathrm{L}^{-1} \mathrm{AQDS}$

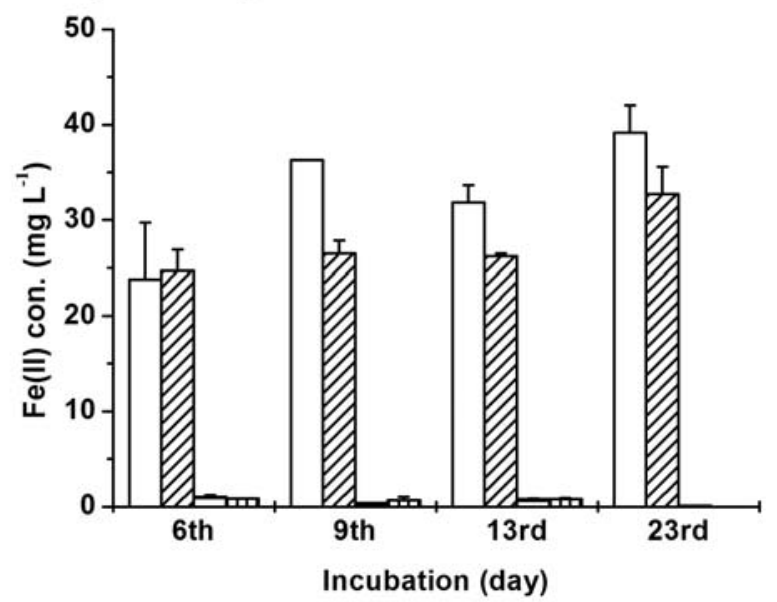

d) with $300 \mu \mathrm{mol} \mathrm{L}{ }^{-1}$ AQDS

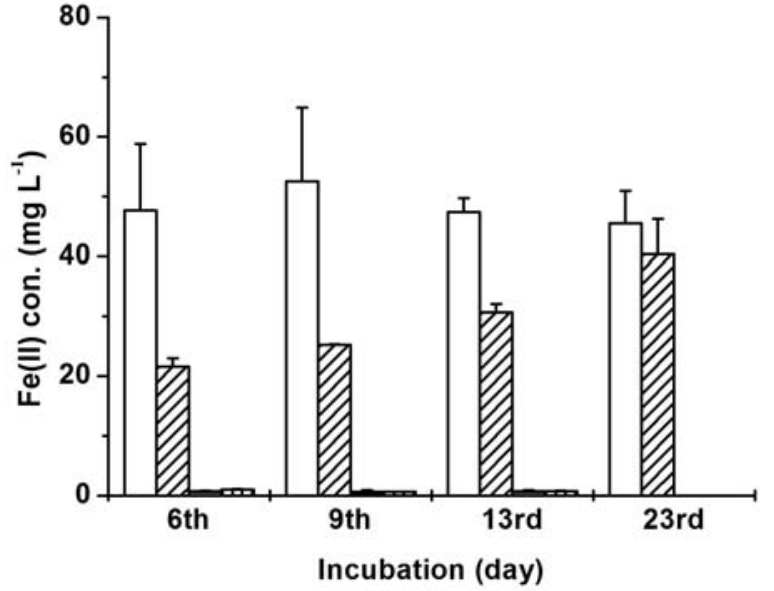

Fig. 3. The influence of AQDS concentrations on the iron reductions of different goethite aggregates. The content of goethite was $6.6 \mathrm{~g} \mathrm{~L}^{-1}$, while the concentrations of AQDS in four treatments were $0,100,150$, and $300 \mu \mathrm{mol} \mathrm{L}^{-1}$.

Kinetic Analysis of the Biological Reductive Dissolution of Hydrogel-Encapsulated Goethite

A kinetic reductive dissolution model was used to simulate the data from the iron reduction experiment to further understand the iron reduction mechanism. Fig. 4 and Table 3 show that the release of Fe(II) ion from goethite was consistent with the kinetic reductive dissolution model. The $\mathrm{R}^{2}$ values were between 0.72 and 0.97 . The $\mathrm{Fe}$ (II) ion concentration followed the order of $2 \%$ hydrogel-encapsulated $6.6 \mathrm{~g} \mathrm{~L}^{-1}$ goethite-AQDS $\approx$ $0.3 \%$ hydrogel-encapsulated $6.6 \mathrm{~g} \mathrm{~L}^{-1}$ goethite-AQDS > $6.6 \mathrm{~g} \mathrm{~L}^{-1}$ goethite-AQDS $>6.6 \mathrm{~g} \mathrm{~L}^{-1}$ goethite $>3.3 \mathrm{~g} \mathrm{~L}^{-1}$ goethite-AQDS $>0.3 \%$ hydrogel-encapsulated $3.3 \mathrm{~g} \mathrm{~L}^{-1}$ goethite-AQDS $\approx 2 \%$ hydrogel-encapsulated $3.3 \mathrm{~g} \mathrm{~L}^{-1}$ goethite-AQDS.

Parameter $k$ and $\log \gamma$ were two parameters of the kinetic reductive dissolution model. As shown in Table 3, in treatments with $6.6 \mathrm{~g} \mathrm{~L}^{-1}$ goethite, the addition of AQDS increased the value of $k$ from $2.95 \times 10^{-4}$ to $5.37 \times 10^{-4}$, but decreased the value of $\log \gamma$ from 3.32 to 3.09 . In $3.3 \mathrm{~g} \mathrm{~L}^{-1}$ goethite treatment, the $k$ and $\log \gamma$ values were both lower

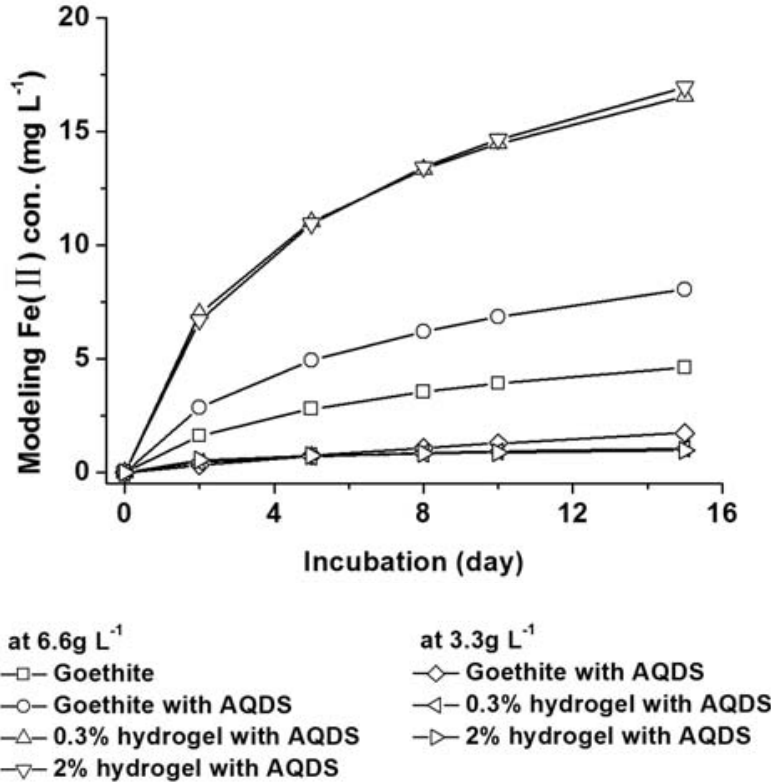

Fig. 4. Kinetic stimulation of iron reduction of different hydrogelencapsulated goethite. 
Table 3. Kinetic parameters of reductive dissolution of goethite in different treatments.

\begin{tabular}{|c|c|c|c|}
\hline & $K$ & $\log \gamma$ & $\mathrm{R}^{2}$ \\
\hline Goethite at $6.6 \mathrm{~g} \mathrm{~L}^{-1}$ & $2.95 \times 10^{-4}$ & 3.32 & 0.74 \\
\hline Goethite at $6.6 \mathrm{~g} \mathrm{~L}^{-1}$ with AQDS & $5.37 \times 10^{-4}$ & 3.09 & 0.76 \\
\hline $0.3 \%$ encapsulated Goethite at $6.6 \mathrm{~g} \mathrm{~L}^{-1}$ with AQDS & $1.70 \times 10^{-3}$ & 2.88 & 0.97 \\
\hline $2 \%$ encapsulated Goethite at $6.6 \mathrm{~g} \mathrm{~L}^{-1}$ with AQDS & $1.48 \times 10^{-3}$ & 2.83 & 0.94 \\
\hline Goethite at $3.3 \mathrm{~g} \mathrm{~L}^{-1} *$ & - & 2.95 & 0.86 \\
\hline Goethite at $3.3 \mathrm{~g} \mathrm{~L}^{-1}$ with AQDS & $8.32 \times 10^{-5}$ & 3.79 & 0.72 \\
\hline $2 \%$ encapsulated Goethite at $3.3 \mathrm{~g} \mathrm{~L}^{-1}$ with AQDS & $5.89 \times 10^{-4}$ & 3.98 & 0.76 \\
\hline
\end{tabular}

* The change of $\mathrm{Fe}(\mathrm{II})$ concentration in the $3.3 \mathrm{~g} \mathrm{~L}^{-1}$ un-encapsualted goethite treatment was limited during incubation, so the data could not be fitted by the kinetic reductive dissolution model.

than those in the treatment with the same concentration of AQDS added but with higher levels of goethite content.

In treatments with $6.6 \mathrm{~g} \mathrm{~L}^{-1}$ goethite, the value of $k$ followed the sequence $0.3 \%$ hydrogel encapsulation with AQDS $\approx 2 \%$ hydrogel encapsulation with AQDS $>$ goethite with AQDS. By contrast, the order for $k$ in treatments with $3.3 \mathrm{~g} \mathrm{~L}^{-1}$ goethite was $2 \%$ hydrogel encapsulation with AQDS $>0.3 \%$ hydrogel encapsulation with AQDS > goethite with AQDS. The value of $\log \gamma$ in treatments with $6.6 \mathrm{~g} \mathrm{~L}^{-1}$ goethite and $100 \mu \mathrm{mol} \mathrm{L}^{-1}$ AQDS followed the order of $2 \%$ hydrogel encapsulation with AQDS $<0.3 \%$ hydrogel encapsulation with AQDS $<$ goethite with AQDS, whereas treatment with $3.3 \mathrm{~g} \mathrm{~L}^{-1}$ goethite showed the opposite trend.

\section{Discussion}

As shown in Fig. 1, the release of $\mathrm{Fe}(\mathrm{II})$ ion from R-soil without AQDS addition was limited. Similarly, in $3.3 \mathrm{~g} \mathrm{~L}^{-1}$ goethite treatments with or without hydrogel encapsulation, the concentrations of $\mathrm{Fe}$ (II) ion were lower than $0.5 \mathrm{mg} \mathrm{L}^{-1}$ during incubation (Fig. 2a). In treatments with $0.3 \%$ or $2 \%$ hydrogel-encapsulated soil/goethite, the release of aqueous $\mathrm{Fe}$ (II) ion was also limited (Figs 1 and 2). In previous reports, biological iron reduction can release $\mathrm{Fe}$ (II) ions in the aqueous phase, but $\mathrm{Fe}$ (II) ions are adsorbed and/or precipitated onto the soils at the same time [5]. The formation of secondary iron minerals, such as siderite and vivianite, also results in the removal of $\mathrm{Fe}$ (II) ions from the aqueous phase [22]. In our other experiment, the concentration of Fe(II) ion was also limited, whereas the iron phase in adsorbed forms and/or precipitates could be detected in the soil sample [11]. By contrast, the concentration of $\mathrm{Fe}(\mathrm{II})$ ion quickly increased to over $2 \mathrm{mg} \mathrm{L}^{-1}$ upon treatment with $6.6 \mathrm{~g} \mathrm{~L}^{-1}$ goethite (Fig. 2b). The increase in goethite level would provide more substrates for biological iron reduction and increase $\mathrm{Fe}(\mathrm{II})$ ion release, which might result in $\mathrm{Fe}$ (II) ion concentration to be higher than that of R-soil or $3.3 \mathrm{~g} \mathrm{~L}^{-1}$ goethite treatments. However, the concentration of $\mathrm{Fe}(\mathrm{II})$ ion was less than $0.5 \mathrm{mg} \mathrm{L}^{-1}$ during incubation with $0.3 \%$ or $2 \%$ hydrogel encapsulation. The possible reason was that hydrogel encapsulation decreased the surface area and pore volume of goethite (as shown in Table 2), thereby reducing the content of bioavailable Fe(II) sites. Thus, the release through biological iron reduction decreased, resulting in the limited increase in $\mathrm{Fe}(\mathrm{II})$ concentration similar to that in encapsulated R-soil or $3.3 \mathrm{~g} \mathrm{~L}^{-1}$ goethite treatment as a result of the adsorption and/or precipitation of Fe(II) ion. Roden and Zachara (1996) [23] suggested that the order of the iron reduction rates of goethite and hematite is consistent with the surface area; the reduction rate of goethite with high surface area and crystalline extent is 50 times the rate of hematite. The iron reduction rate is dependent on the surface area of hematite exposed to Geobacter sulfurreducens [13]. Thus, the structural properties played an important role during biological iron reduction.

With the addition of AQDS, the concentration of $\mathrm{Fe}(\mathrm{II})$ ion in treatment with R-soil or either concentrations of goethite increased during incubation (Figs 1 and 2). In particular, the concentration of $\mathrm{Fe}(\mathrm{II})$ ion was higher with $100 \mu \mathrm{mol} \mathrm{L}{ }^{-1}$ AQDS than that without AQDS upon $6.6 \mathrm{~g} \mathrm{~L}^{-1}$ goethite treatment. As previously reported, AQDS can prompt biological iron reduction as an electron shuttle compound [24]. Thus, the concentration of Fe(II) ion increased compared with treatment without AQDS. Furthermore, as simulated by the kinetic reductive dissolution model (Table 3), the addition of AQDS increased the value of $k$ but decreased the value of $\log \gamma$ in treatments with $6.6 \mathrm{~g} \mathrm{~L}^{-1}$ goethite. Parameter $k$ was the initial rate constant, so a high $k$ value indicated an increase in the initial rate of reductive dissolution. $\log \gamma$ represents the long-term extent of $\mathrm{Fe}$ (II) ion release by bioreduction, which depends on the morphology, size distribution, and reactive site density of the iron mineral undergoing dissolution. The decrease in $\log \gamma$ indicated an increase in the long-term extent of $\mathrm{Fe}(\mathrm{II})$ ion release [22]. This result suggested that the addition of AQDS increased the initial dissolution rate and improved the long-term extent of $\mathrm{Fe}(\mathrm{II})$ ion release, leading to the high performance 
of $\mathrm{Fe}(\mathrm{II})$ ion release compared to treatment without AQDS. Kukkadapu et al. (2006) [25] reported a similar description; the electron shuttle mechanism of AQDS enabled S. putrefaciens to quickly react with $\mathrm{Fe}(\mathrm{III})$ on the surface of the iron mineral and Fe(III) within the pore structure, thereby increasing the rate and extent of iron reduction.

In addition, the concentration of $\mathrm{Fe}(\mathrm{II})$ ion in R-soil treatments with $100 \mu \mathrm{mol} \mathrm{L}-1$ AQDS followed the order of unencapsulated treatment $>0.3 \%$ encapsulation treatment $>2 \%$ encapsulation treatment. Once again, the structural properties influenced biological iron reduction. With the increase in the cross-linker ratio, the surface area and pore volume of R-soil decreased (Table 1). Thus, the bioavailable $\mathrm{Fe}$ (III) sites decreased as the cross-linker ratio increased, leading to a decrease in the Fe(II) concentration. However, the effect of hydrogel encapsulation on the release of Fe(II) ion from goethite aggregates varied. During treatment with $3.3 \mathrm{~g} \mathrm{~L}^{-1}$ goethite, the concentration of $\mathrm{Fe}(\mathrm{II})$ ion followed the order of unencapsulated treatment $>>0.3 \%$ encapsulation treatment $>2 \%$ encapsulation treatment. However, with the same concentration of AQDS, the release of $\mathrm{Fe}(\mathrm{II})$ ion from $6.6 \mathrm{~g} \mathrm{~L}^{-1}$ goethite treatment followed the order of unencapsulated treatment $<<0.3 \%$ encapsulation treatment $<2 \%$ encapsulation treatment. This result suggested that the influence of structural properties on biological iron reduction was also dependent on the content of iron-containing substrates. In addition, the value of $k$ increased with the cross-linker ratio during treatment with $3.3 \mathrm{~g} \mathrm{~L}^{-1}$ or $6.6 \mathrm{~g} \mathrm{~L}^{-1}$ goethite, as shown in the simulation (Table 3 ).

The increased $k$ value suggested that the initial rate of $\mathrm{Fe}(\mathrm{II})$ ion release increased with hydrogel encapsulation despite the content of goethite in the system. The possible reason was that more strains of Shewanella reacted with the same goethite content compared with unencapsulated treatment under the same conditions because the surface area of goethite aggregate decreased after encapsulation. However, the effect of hydrogel encapsulation on the change in $\log \gamma$ was dependent on the content of $\mathrm{Fe}$ (III)containing substrate. The value of $\log \gamma$ decreased as the cross-linker ratio increased during $6.6 \mathrm{~g} \mathrm{~L}^{-1}$ goethite treatment, which suggested that the long-term extent of $\mathrm{Fe}(\mathrm{II})$ ion release increased. By contrast, the change in log $\gamma$ value with the increase in the cross-linker ratio during $3.3 \mathrm{~g} \mathrm{~L}^{-1}$ goethite treatment indicated that the long-term extent of $\mathrm{Fe}(\mathrm{II})$ ion release decreased. As previously mentioned, the change in the aqueous $\mathrm{Fe}(\mathrm{II})$ ion concentration was controlled by the interaction between $\mathrm{Fe}(\mathrm{II})$ ion release through biological iron reduction and the adsorption/precipitation of Fe(II) ion. The surface area decreased as the cross-linker ratio in $6.6 \mathrm{~g} \mathrm{~L}^{-1}$ goethite treatment increased, leading to the simultaneous decrease in both bioavailable $\mathrm{Fe}$ (III) sites and Fe(II) adsorption/ precipitation sites. However, the increase in the long-term extent of $\mathrm{Fe}(\mathrm{II})$ ion release suggested that the decrease in $\mathrm{Fe}(\mathrm{II})$ removal by hydrogel encapsulation played a more important role in the release of Fe(II) ion by bioreduction. In contrast, the decrease in bioavailability of goethite during $3.3 \mathrm{~g} \mathrm{~L}^{-1}$ goethite treatment had a more significant role in the change in $\mathrm{Fe}(\mathrm{II})$ ion concentration. This result might be due to the different ratios of AQDS to goethite. With the same concentration of AQDS, the ratio of AQDS to goethite during $6.6 \mathrm{~g} \mathrm{~L}^{-1}$ goethite treatment was twice the ratio in $3.3 \mathrm{~g} \mathrm{~L}^{-1}$ goethite treatment. Thus, lower bioavailable $\mathrm{Fe}(\mathrm{III})$ sites exerted a greater influence on treatment with $3.3 \mathrm{~g} \mathrm{~L}^{-1}$ compared with $6.6 \mathrm{~g} \mathrm{~L}^{-1}$ with a sufficient supply of AQDS. However, the ratio of AQDS to goethite increased with AQDS addition. Therefore, the interaction of both bioavailable Fe(III) sites and $\mathrm{Fe}$ (II) adsorption/precipitation sites was similar to that in $3.3 \mathrm{~g} \mathrm{~L}^{-1}$ treatment.

In this study, the concentration of ions in unencapsulated treatment was indeed reduced to a concentration lower than that of $2 \%$ encapsulation treatment after AQDS was increased to $150 \mu \mathrm{mol} \mathrm{L} \mathrm{L}^{-1}$ or $300 \mu \mathrm{mol} \mathrm{L} \mathrm{L}^{-1}$ (Fig. 3). However, further research should be conducted to fully understand the influence of structural properties on iron reduction by $S$. oneidensis MR-1.

\section{Conclusions}

Our data indicated that the release of $\mathrm{Fe}(\mathrm{II})$ ions from the biological iron reduction process was influenced by the structural property and concentration of the electron shuttle compound. The effect of structural property varied with different iron mineral contents. The simulation of the kinetic reductive dissolution model suggested that the initial rate and long-term extent of iron reduction differed among goethite aggregates, depending on the structural property and environmental condition. These differences resulted in different performances of $\mathrm{Fe}(\mathrm{II})$ ion release during the biological reduction process.

\section{Acknowledgements}

This study was financially supported by the Natural Science Foundation of China under grant Nos. 21177121, 41301328, and 41373092.

\section{References}

1. ZACHARA J.M., KUKKADAPU R.K., PERETYAZHKO T., BOWDEN M., WANG C.M., KENNEDY D.W., MOORE, D., AREY B. The mineralogic transformation of ferrihydrite induced by heterogeneous reaction with bioreduced anthraquinone disulfonate (AQDS) and the role of phosphate. Geochim. Cosmochim. Ac. 75 (21), 6330, 2011.

2. LIU Y., LI F.B., XIA W., XU J.M., YU X.S. Association between ferrous iron accumulation and pentachlorophenol degradation at the paddy soil-water interface in the presence of exogenous low-molecular-weight dissolved organic carbon. Chemosphere 91 (11), 1547, 2013.

3. FREDRICKSN J.K., ZACHARA J.M., KENNEDY D.W., KUKKADAPU R.K., MCKINLEY J.P., HEALD S.M., LIU C., PLYMALE A.E., SMITH S.C. Reduction of $\mathrm{TcO}_{4}$ by 
sediment-associated biogenic Fe(II). Geochim. Cosmochim. Ac. 68, 3171, 2004.

4. KOMLOS J., KUKKADAPU R.K., ZACHARA J.M., JAFFE P.R. Biostimulation of iron reduction and subsequent oxidation of sediment containing Fe-silicates and Fe-oxides: effect of redox cycling on Fe(III) bioreduction. Water Res. 41, 2996, 2007.

5. ZACHARA J.M., KUKKADAPU R.K., FREDICKSON J.K., GORBY Y.A., SMITH S.C. Biomineralization of poorly crystalline $\mathrm{Fe}(\mathrm{III})$ oxides by dissimilatory metal reducing bacteria (DMRB). Geomicrobiol. J. 19, 179, 2002.

6. SCHLEINITZK.M., SCHMELING S., JEHMLICHN., VON BERGEN M., HARMS H., KLEINSTEUBER S., VOGT C., FUCHS G. Phenol degradation in the strictly anaerobic iron-reducing bacterium Geobacter metallireducens GS-15. Appl. Environ. Microbiol. 75 (12), 3912, 2009.

7. COOPER D.C., PICARDAL F.F., COBY A.J. Interactions between microbial iron reduction and metal geochemistry: effect of redox cycling on transition metal speciation in iron bearing sediments. Environ. Sci. Technol. 40, 1884, 2006.

8. HU C.H., ZHANG Y.C., ZHANG L., LUO W.S. Effects of Microbial Iron Reduction and Oxidation on the Immobilization and Mobilization of Copper in Synthesized Fe(III) Minerals and Fe-Rich Soils. J. Microbiol. Biotechnol. 24 (4), 534, 2014.

9. ZHANG T., GANNON S.M., NEVIN K.P., FRANKS A.E., LOVLEY D.R. Stimulating the anaerobic degradation of aromatic hydrocarbons in contaminated sediments by providing an electrode as the electron acceptor. Environ. Microbiol. 12 (4), 1011, 2010.

10. CUTTING R.S., CORKER V.S., FELLOWES J.W., LLOYD J.R., VAUGHAN D.J. Mineralogical and morphological constraints on the reduction of Fe(III) minerals by Geobacter sulfurreducens. Geochim. Cosmochim. Ac. 73, 4004, 2009.

11. ZHANG Y.C., HU C.H., LUO W.S. Influences of electron donor, bicarbonate and sulfate on bioreduction processes and manganese/copper redistributions among minerals in a water-saturated sediment. Soil Sediment Contam. 23 (1), 94, 2014.

12. BOSE S., HOCHELLA JR M.F., GORBY Y.A., KENNEDY D.W., MCCREADY D.E., MADDEN A.S., LOWER B.H. Bioreduction of hematite nanoparticles by the dissimilatory iron reducing bacterium Shewanella oneidensis MR-1. Geochim. Cosmochim. Ac. 73, 962, 2009.

13. YAN B., WRENN B.A., BASAK S., BISWAS P., GIAMMAR D.E. Microbial reduction of Fe(III) in hematite nanoparticles by Geobacter sulfurreducens. Environ. Sci. Technol. 42, 6526, 2008.
14. GERLACH R., FIELD E.K., VIAMAJALA S., PEYTON B.M., APEL W.A., CUNNINGHAM A.B. Influence of carbon sources and electron shuttles on ferric iron reduction by Cellulomonas sp. Strain ES6. Biodegradation 22, 983995, 2011.

15. AMSTAETTER K., BORCH T., KAPPLER, A. Influence of humic acid imposed changes of ferrihydrite aggregation on microbial Fe(III) reduction. Geochim. Cosmochim. Ac. 85, 326, 2012.

16. PIEPENBROCK A., DIPPON U., PORSCH K., APPEL E., KAPPLER A. Dependence of microbial magnetite formation on humic substance and ferrihydrite concentrations. Geochim. Cosmochim. Ac. 75, 6844, 2011.

17. LOVLEY D.R., PHILLIPS E.J.P. Organic matter mineralization with reduction of ferric iron in anaerobic sediments. Appl. Envrion. Microbiol. 51 (4), 683, 1986.

18. SPALDING BP, BROOKS SC, WATSON DB. Hydrogelencapsulated soil: a tool to measure contaminant attenuation in situ. Envrion. Sci. Technol. 44, 3047, 2010.

19. LARSON O., POSTMA D. Kinetics of reductive bulk diss olution of lepidocrocite, ferrihydrite, and goethite. Geochim. Cosmochim. Ac. 65 (9), 1367, 2001.

20. RODEN E.E. Geochemical and microbiological controls on dissimilatory iron reduction. C R Geosci. 338, 456, 2006.

21. DAVRANCHE M., DIA A., FAKIH M., NOWACK B., GRUAU G., ONA-NGUEMA G., PETITJEAN P., MARTIN S., HOCHREUTENER R. Organic matter control on the reactivity of $\mathrm{Fe}(\mathrm{III})$-oxyhydroxides and associated As in wetland soils: a kinetic modeling study. Chem. Geol. 335, 24, 2013.

22. RODEN E.E., ZACHARA J.M. Microbial reduction of crystalline iron (III) oxides: Influence of oxide surface area and potential for cell growth. Environ. Sci. Technol. 30 (5), 1618,1996

23. DONG H.L., FREDRICKSON J.K., KENNEDY D.W., ZZCHARA J.M., KUKKADAPU R.K., ONSTOTT T.C. Mineral transformation associated with the microbial reduction of magnetite. Chem. Geol. 169, 299, 2000.

24. LI X.M., LIU L., LIU T.X., YUAN T., ZHANG W., LI F.B., ZHOU S.G., LIY.T. Electron transfer capacity dependence of quinone-mediated $\mathrm{Fe}$ (III) reduction and current generation by Klebsiella pneumoniae L17. Chemosphere 92 (2), 218, 2013.

25. KUKKADAPU R.K., ZACHARA J.M., FREDRICKSON J.K., MCKINLEY J.P., KENNEDY D.W., SMITH S.C., DONG H.L. Reductive biotransformation of $\mathrm{Fe}$ in shalelimestone saprolite containing Fe (III) oxides and Fe (II)/ Fe (III) phyllosilicates. Geochim. Cosmochim. Ac. 70 (14), 3662, 2006. 